$<$ Back to results 1 of 1

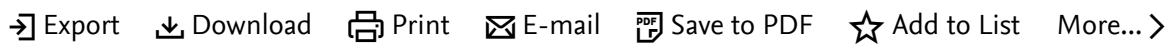

Full Text

2020 8th International Conference on Cyber and IT Service Management, CITSM 2020 • 23 October 2020 • Article number 9268899 • 8th International Conference on Cyber and IT Service Management, CITSM 2020 • Virtual, Pangkal Pinang • 23 October 2020 through 24 October 2020 • Code 165630

Document type

Conference Paper

Source type

Conference Proceedings

ISBN

978-172817701-4

DOI

10.1109/CITSM50537.2020.9268899

View more $\checkmark$

\section{Investigation of IT Competence and Readiness of IT Students Facing the Industrial Revolution 4.0}

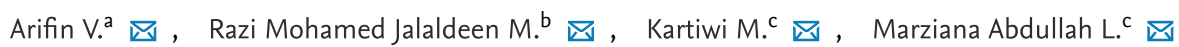

䀳 Save all to author list

a Syarif Hidayatullah State Islamic University, Informatics Department, Jakarta, Indonesia

${ }^{b}$ University Kelaniya, Department of Commerce and Financial Management, Colombo, Sri Lanka

${ }^{\mathrm{c}}$ International Islamic University Malaysia, Department of Information System, Kuala Lumpur, Malaysia

\begin{tabular}{l|l|l}
1 & 7 & View all metrics > \\
Citation in Scopus & Views count (?)
\end{tabular}

Full text options $\vee$

Abstract

Author keywords

Indexed keywords

Sustainable Development Goals 2021

SciVal Topics

Metrics

Funding details

Abstract
Cited by 1 document

Organizational agility in industry 4.0: A systematic literature review

Mrugalska, B. , Ahmed, J.

(2021) Sustainability (Switzerland)

View details of this citation

Inform me when this document is cited in Scopus:

Set citation alert >

Related documents

Performance improvement through human capital strtegic for civil servant

Soehari, T.D. , Budiningsih, I. , Bakdi

(2017) International Journal of Applied Business and Economic Research

Improvement of the career path of the government internal supervisory apparatus (Apip) in the regional government of soppeng regency

Aswar, Hendra, Misbahuddin (2021) Proceedings of the International Conference on Industrial Engineering and Operations Management

Design of Competency Test Model for Electrical Installation Automation Based Project Learning for Electrical Engineering Students

Haryudo, S.I. , Ekohariadi , Munoto

(2020) Proceeding - 2020 3rd International Conference on Vocational Education and Electrical Engineering: Strengthening the framework of Society 5.0 through Innovations in Education, Electrical, Engineering and Informatics Engineering, ICVEE 2020

View all related documents based on references

Find more related documents in Scopus based on:

Authors > Keywords > 
The focus of this research is to investigate IT competence and IT students ' readiness to face the industrial revolution 4.0 based on student perception. In this preliminary study, a survey was distributed through an online survey to 50 Indonesian IT students . Respondents were students of Syarif Hidayatullah State Islamic University who were between 18-24 years old. The results show that the hard skills that are more in demand are Information Technology Governance and Management, and the least desirable is Information Technology Enterprise Architecture. Regarding soft skills, most of the students agreed that the important trait the IT graduates should uphold to is honesty. In general, 92 percent of respondents were ready to enter the era of the industrial revolution 4.0. These findings confirm that competence in the form of hard skills, soft skills, and readiness to face the era of the industrial revolution 4.0 is one of the core elements to determine the extent of preparation of IT students facing the era of the industrial revolution 4.0. Enhancing one competency to embark on the new industrial revolution is a must, and agility is indeed a critical identity that must be inherent in IT students in facing the industrial revolution 4.0. (C) 2020 IEEE.

Author keywords

Competence ; Industry Revolution 4.0; IT Student; Readiness ; Soft Skills

Indexed keywords

Sustainable Development Goals 2021 (i) New

SciVal Topics (i)

Metrics

Funding details

References (27)

View in search results format $>$

All

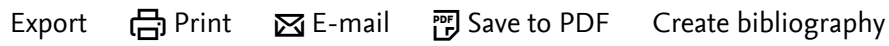

1 (2018) Digitalisasi Ekonomi Hilangkan 50 Juta Peluang Kerja antaranews. com. Selasa, 6 Februari 2018 19: 15 WIB. [Acessed, 3 October 2020]

https://www.antaranews.com/berita/683679/digitalisasi-ekonomihilangkan50-juta-peluang-kerja

2 Ahmad, M., Karim, A.A., Din, R., Albakri, I.S.M.A.

Assessing ICT competencies among postgraduate students based on the 2lst Century ICT Competency Model

(Open Access)

(2013) Asian Social Science, 9 (16 SPL), pp. 32-39. Cited 17 times. http://www.ccsenet.org/journal/index.php/ass/article/download/32375/18848 doi: $10.5539 /$ ass.v9n16p32

View at Publisher

3 Arikunto, $\mathrm{S}$.

(1999) Prosedur Penelitian Suatu Pendekatan Praktek. Cited 565 times. Jakarta: Rineka Cipta. 
4 Blanqui, L.-A.

(1837) Industrial Revolution

New York: Putnam, translation

5 Deaconu, A., Nistor, C.S.

Competences in romanian higher education-an empirical investigation for the business sector

(2015) Studies in Higher Education, pp. 1-23.

6 Engels, $\mathrm{F}$.

(1975) The Condition of the Working Class in England in Collected Works of Karl Marx and Frederick Engels, 4, p. 1844.

New York: International Publishers, firstly published in

7 Flores, E., Xu, X., Lu, Y.

Human Capital 4.0: a workforce competence typology for Industry 4.0

(2020) Journal of Manufacturing Technology Management, 31 (4), pp. 687-

703. Cited 24 times.

http://www.emeraldinsight.com/info/journals/jmtm/jmtm.jsp doi: 10.1108/JMTM-08-2019-0309

View at Publisher

8 (2000) Konsep, Karakteristik Dan Implementasi. Jakarta. Grasindo

Gordon. Kompetensi

9 Kennewell, S., Parkinson, J., Tanner, H.

(2000) Developing the ICT Capable School. Cited 69 times.

London: Routledge Falmer

10 (2018) Daftar Unit Kompetensi Okupasi Dalam Kerangka Kualifikasi Nasional Indonesia Bidang Teknologi Informasi Dan Komunikasi

Kominfo. Jakarta

11 Maria, S., Darma, D.C., Amalia, S., Hakim, Y.P., Pusriadi, T.

Readiness to face industry 4.0

(2019) International Journal of Scientific and Technology Research, 8 (9), pp. 2363-2368. Cited 2 times.

http://www.ijstr.org/final-print/sep2019/Readiness-To-Face-Industry-40.pdf

\section{McKinsey}

(2017) Jobs Lost, Jobs Gained: Workforce Transitions in A Time of Automation. Cited 269 times.

Global Institute 
(1984) Measurement Based Evaluation of Teachers Performance. Cited 42 times.

New York: Long Man

14 (2016) Global Competency Model for Graduate Degree Programs in Information Systems. Cited 24 times.

15 (2018) Pedoman Akademik Program Strata Satu UIN Syarif Hidayatullah Jakarta 2018/2019

31 Agustus [Acessed, 1 October 2020]

https://pbauinjkt.id/_file/Pedoman/Akademik/Pedoman_Akademik_S1_2018. 2019.pdf

17 Morrar, R., Arman, H., Mousa, S.

The fourth industrial revolution (industry 4. 0): A social innovation perspective technol

(2017) Innov. Manag. Rev., 7 (11), pp. 12-20. Cited 155 times.

18 Robbins, S.P.

(2007) Organizational Behavior. Cited 3135 times.

Clifs Prentice Hall, New Jersey

19 Schwab, K.

(2017) The Fourth Industrial Revolution. Cited 2968 times.

Swiss Federal: Crown Business

20 Siregar, N., Sahirah, R., Harahap, A.A.

Konsep kampus merdeka belajar di era revolusi industri 4. 0

(2020) Fitrah: Journal of Islamic Education, l (1), pp. 141-157.

21 Sugiyono

(2008) Statistika Untuk Penelitian. Cited 294 times.

Bandung: Alfabeta Supardi. 1979. Statistik. Bandung: Fakultas Tarbiyah IAIN

Sunan Gunung Jati 
$\square 23$ Pengaruh Kreativitas Guru Dalam Pembelajaran Dan Kecerdasan Emosional Siswa Terhadap Prestasi Belajar Ekonomi Pada Siswa Kelas X Di Sma Negeri 89 Jakarta

(2017) Econosains Jurnal Online Ekonomi Dan Pendidikan, 14 (1), pp. 105-

15112.

Suparno.

24 Sutrisno, H.E.

(2011) Manajemen Sumber Daya Manusia. Cited 325 times.

Ed. 1. Cet. 3. Kencana. Jakarta

25 Spencer, L.M., Spencer, S.M.

(1993) Competency at Work, p. 5. Cited 1802 times.

New York: John Wiely \& Sons

26 Tadesse, T., Gillies, R.M., Campbell, C.

Assessing the dimensionality and educational impacts of integrated ICT literacy in the higher education context

(Open Access)

(2018) Australasian Journal of Educational Technology, 34 (1), pp. 88-

101. Cited 15 times.

https://ajet.org.au/index.php/AJET/article/download/2957/1471

doi: 10.14742/ajet.2957

View at Publisher

\27 Torres-Gastelú, C.A., Kiss, G.

Perceptions of students towards ICT competencies at the University (Open Access)

(2016) Informatics in Education, 15 (2), pp. 319-338. Cited 8 times. http://www.mii.lt/informatics_in_education/pdf/infedu.2016.16.pdf doi: 10.15388/infedu.2016.16

View at Publisher

(C) Copyright 2020 Elsevier B.V., All rights reserved.

\section{About Scopus}

What is Scopus

Content coverage

Scopus blog

Scopus API

Privacy matters

\section{Language}

日本語に切り替える

切换到简体中文

切換到繁體中文

Русский язык

\section{Customer Service}

Help

Contact us 
Copyright (C) Elsevier B.V 九. All rights reserved. Scopus® is a registered trademark of Elsevier B.V.

We use cookies to help provide and enhance our service and tailor content. By continuing, you agree to the use of cookies. 